\title{
Horoscope, Predestination and Merit in Ancient Judaism ${ }^{1}$
}

\section{Francis Schmidt}

\begin{abstract}
For the Essenes, 'Destiny is the master of everything'. This observation by Josephus is confirmed by the evidence of the Dead Sea manuscripts. The doctrine of the Essenes of Qumran, which places astral determinism in the service of predestination, is compared in this essay to that of the Sages of the generation of Rabbi Akiva. Faced with the questions of length of life and premature death, what place does the doctrine of the Sages accord to freedom of choice? Analysis of the Testament of Abraham and TB Shabbat 156a-b shows that for certain Egyptian circles of Hellenised Judaism, as for the Sages, length of life and the kind of death are not solely determined by the theme of geniture (mazzal), but depend equally on merit. Indeed, far from making the decrees of genethlialogy ineluctable, it is possible, by choosing righteous conduct, to escape predictions of premature death given by the horoscope.
\end{abstract}

\section{Genethlialogy and Predestination in Qumran}

The clearest evidence that astrology or, more precisely, the science of the horoscope or genethlialogy, is one of the subjects discussed in the Dead Sea scrolls, is a document called 4QHoroscope (4Q186). I shall not dwell here on the debates aroused by this document, ${ }^{2}$ but merely affirm that on

\footnotetext{
${ }^{1}$ I would like to express all my thanks to Nissim Marshall who translated this paper from the French.

${ }^{2}$ On horoscopes in the Dead Sea Scrolls see M. Albani, 'Horoscopes in the Qumran Scrolls', in The Dead Sea Scrolls after Fifty Years. A Comprehensive Assessment, eds P.W. Flint \& J.C. VanderKam (Leiden/Boston, 1999), vol. 2, pp. 279-330; 'Horoscopes', in Encyclopedia of the Dead Sea Scrolls, eds L. H. Schiffman \& J. C. VanderKam (Oxford, 2000), vol. 1, pp. 370-373. For the interpretation of 4QHoroscope (olim 4QCryptic), see F. Schmidt, 'Astrologie juive ancienne. Essai d'interprétation de 4QCryptique (4Q186)', Revue de Qumrân, $\mathrm{n}^{\circ}$ 69, t. 18, fasc. 1, 1997, pp. 125-41; 'Ancient Jewish Astrology. An Attempt to Interpret 4QCryptic (4Q186)', in Biblical Perspectives: Early Use
}

Francis Schmidt, 'Horoscope, Predestination and Merit in Ancient Judaism', Culture And Cosmos, Vol. 11 no 1 and 2, Spring/Summer and Autumn/Winter 2007 pp. 27-41.

www.CultureAndCosmos.com 
28 Horoscope, Predestination and Merit in Ancient Judaism

two occasions, 4QHoroscope uses a non-biblical term, môlad, which is generally acknowledged today to be a technical term of the astrological vocabulary, translated as 'geniture'.

The context in which the word is employed in 4QHoroscope (4Q186) highlights the technical, astrological meaning of 'geniture': 'And this is the (theme of) geniture ( $h m w l d)$ in which he was born: in the foot of Taurus (...). He will be poor' (4Q186, 1 ii 8-9). Similarly, in fragment 2 i 8: 'And such is his geniture (mwldw) [in which] he is born'. The mention of the sign of the zodiac, 'in the foot of Taurus', and the prediction, 'he will be poor', while serving to identify 4Q186 as a horoscope, indicate without any doubt that the semantic register to which the noun môlad belongs here is that of astrology.

Môlad in the sense of 'geniture' 4

The concordance of the Dead Sea scrolls indicates 21 occurrences of the word môlad, 15 in Hebrew and 6 in Aramaic. ${ }^{5}$ Of these 21 occurrences,

and Interpretation of the Bible in Light of the Dead Sea Scrolls, eds M. E. Stone \& E. G. Chazon (Leiden, 1998), pp. 189-205 [note: in Schmidt, 'Ancient Jewish Astrology', 1998, pp. 204-05, figs 1, 2, 3 are wrong; they must be replaced by figs 1, 2, 3, from Schmidt, 'Astrologie juive ancienne', 1997, pp. 133, 134, 135]; more recently, M. Popović, Reading the Human Body. Physiognomics and Astrology in the Dead Sea Scrolls and Hellenistic-Early Roman Period Judaism (Proefschrift: Rijksuniversiteit Groningen, 2006) [hereafter Popović, Body], pp. $119-71$.

${ }^{3}$ For the text, see J. M. Allegro, Qumrân Cave 4. I (4Q158-4Q186), Discoveries in the Judaean Desert of Jordan V (Oxford, 1968), pp. 89 and 91. For a new reconstruction of the fragments of 4Q186, see Popović, Body, pp. 18-32, esp. pp. 29-31.

${ }^{4}$ On môlad in the sense of 'geniture', see F. Schmidt, “"Recherche son thème de géniture dans le mystère de ce qui doit être". Astrologie et prédestination à Qoumrân', in Qoumrân et le judaïsme du tournant de notre ère, eds A. Lemaire \& S. C. Mimouni (Paris-Louvain, 2006) [hereafter Schmidt, 'Recherche'], pp. 53-55.

${ }^{5}$ M. G. Abegg Jr., J. E. Bowley \& E. M. Cook, The Dead Sea Scrolls Concordance (Leiden - Boston, 2003), I, p. 430 (Hebrew); II, p. 868 (Aramaic). 
the astrological meaning of 'geniture' is certain in 16 of them. ${ }^{6}$

Among the nominal syntagmas in which môlad is employed in the plural, one of the most interesting is the expression bet môladîm. This expression probably means the 'places' or 'houses' occupied by the planets in the signs of the zodiac at the time of the birth or conception of an individual whose destiny they affect. ${ }^{7}$ I therefore propose to translate this expression literally as 'House of Geniture'. Thus in 4QMysteries (4Q299) frag. 3 ii 13, it is said of God the creator who fully preordains the fate of humanity: 'the pl]an of the House of Geniture $([\mathrm{m}] \mathrm{h} s \mathrm{sb}$ byt mwldym), He opens (pth) bef[ore us] ${ }^{8}$. The horoscope or 'House of Geniture', which is revealed ('open', pth, can be understood in the sense of 'reveal'), is mentioned here in a context of predestination.

\section{The theme of geniture (môlad) and the 'Mystery that is to be' (raz nihyeh) ${ }^{9}$}

Furthermore, the analysis of the contexts in which the word môlad or the syntagma bet môladîm appears sheds light on the relation of this astrological vocabulary with another syntagma, raz nihyeh, which can be translated as 'the mystery that is to be'.

In 4QInstruction, those who have to take a decision or who are in difficulty are advised to scrutinise the 'Mystery that is to be' to consider therein the theme of geniture of their friends and relations. Thus when the

\footnotetext{
${ }^{6}$ Two times in $4 \mathrm{QHoroscope}(4 \mathrm{Q} 186)$; seven times in 4 QInstruction (4Q415416-417-418); four times in 4QMysteries (4Q299); and three times in Aramaic in 4QBirth of Noah (4Q534).

${ }^{7}$ See M. Morgenstern, 'The Meaning of byt mwldym in the Qumran Wisdom Texts', Journal of Jewish Studies (2000), vol. 51, pp. 141-44. On the theory of planetary domiciles in relation to the theme of geniture, see A. Bouché-Leclercq, L'Astrologie grecque (Paris, 1899) [hereafter Bouché-Leclercq], pp. 182-92.

${ }^{8}$ For the text, see L. H. Schiffman, '4Q299-301. Mysteries', in Qumran Cave 4. $X V$ Sapiential Texts, Part 1, eds T. Elgvin, M. Kister, T. Lim et al., Discoveries in the Judaean Desert XX (Oxford, 1997), pp. 41-42. I follow the restitution $\operatorname{lp}[$ nynw, 'be[fore us]', proposed by E. J. C. Tigchelaar, 'Your Wisdom and Your Folly. The Case of 1-4Qmysteries', in Wisdom and Apocalypticism in the Dead Sea Scrolls and in the Biblical Tradition, ed. F. García Martínez (Leuven/Paris/Dudley, MA, 2003), p. 88, because of the first person plural attested in the next line.

${ }^{9}$ On the theme of geniture and the 'Mystery that is to be', see Schmidt, 'Recherche', pp. 55-60.
} 
30 Horoscope, Predestination and Merit in Ancient Judaism

'poor' marries, he is advised to enquire into the predetermined genethlialogical particularities of his wife: 'You have taken a wife in your poverty, take [her] theme of geniture [...] according to the Mystery that is to be' (4Q416, 2 iii 20-21).

Similarly, the consultation of the 'Mystery that is to be' and the issue of the theme of geniture leads to the knowledge of eschatological retributions. Thus, he who is afflicted by mourning is advised: '[Regard the mystery] that is to be and take the theme of geniture (which decides) salvation. Know who inherits glory and elevation' (4Q417, 2 i 11 [olim $1 \mathrm{i}]) .{ }^{10}$ Consultation of the horoscope serves to know the 'inheritance', that is, the fate for which every one is predestined. ${ }^{11}$

The exegetes of 4QInstruction highlighted the fact that the 'Mystery that is to be' (raz nihyeh) designates a body of esoteric knowledge acquired by revelation. This body of revealed doctrines extends from cosmogony to eschatology and includes precepts of wisdom governing human conduct. Thus we find that genethlialogy, in which BouchéLeclercq saw 'the sanctuary of astrology, ${ }^{12}$ is also transmitted by the revelation of this doctrinal body. As emerges from the uses of the lexicographic family of môlad in the sense of 'geniture', genethlialogy as conceived in Qumran is not simply a divinatory technique recommended to humans for taking decisions or for making individual predictions. Genethlialogy is inscribed in the very heart of the divine Plan for creation.

As for the one who day and night scrutinises and meditates the 'Mystery that is to be', he is invited to put genethlialogy into practice. Yet for him, the interrogation of the horoscope is not limited to a

\footnotetext{
${ }^{10}$ J. Strugnell \& D. Harrington, Sapiential Texts, Part 2. 4QInstruction, (Qumran Cave 4 XXIV. Discoveries in the Judaean Desert XXXIV, Oxford, 1999), p. 173, proposed the reading $k b w d w^{\prime} \mathrm{ml}$, and translated (p. 176): 'Who is to inherit glory and toil'. I follow the reading of E. Puech, 'Apports des manuscrits de Qoumrân à la croyance à la résurrection dans le judaïsme ancien', in Qoumrân et le judaïsme du tournant de notre ère, eds A. Lemaire \& S. C. Mimouni (Paris/Louvain, 2006), p. 88, who corrects: kbwd w'l, and translates: 'glory and elevation'. See in addition E. J. C. Tigchelaar, To Increase Learning for the Understanding Ones. Reading and Reconstructing the Fragmentary Early Jewish Sapiential Text 4QInstruction (Leiden/Boston/Cologne, 2001), pp. 55-56.

${ }^{11}$ See in the same sense A. Caquot, 'Les textes de sagesse de Qoumrân (Aperçu préliminaire)', Revue d'Histoire et de Philosophie Religieuses (1996), vol. 76, no. 1, p. 9 , note for line 11 .

${ }^{12}$ Bouché-Leclercq, p. 372.
}

Culture and Cosmos 
decision-making technique. For whoever has meditated on the 'Mystery that is to be', and knows that astrology is an instrument for accomplishing the divine Plan, interrogating the horoscope is nothing less than interrogating the divine Will in order to act in conformity with it. In doing so, the discerning disciple penetrates the secret of divine Thought. For those who can discern (mêvîn), the interrogation of the theme of geniture, his own or that of his friends and relations, teaches him the fate predestined by divine Design: a hidden aspect of the creative activity of God (Ma'aseh bereshit) which is thereby unveiled.

All things considered, the analysis of the lexicographic uses of môlad in the Qumran documents on wisdom sheds light on a genethlialogy that reveals the divine Design for the creation and places astral determinism in the service of predestination.

\section{Mazzal and merit, from the Testament of Abraham to Rabbi Akiva}

On three occasions Josephus describes the diverging positions of the main Jewish 'sects' of his time in dealing with the question of which part of an event depends on human will and which should be ascribed to Fate. ${ }^{13}$ He says, 'The sect of Essenes declares that Fate (heimarmenê) is mistress of all things, and that nothing befalls men unless it be in accordance with her decree.' (Antiquities XIII, 172). ${ }^{14}$

To emphasise this sort of fatality of predestination and the exiguous limits of human freedom, as conceived and experienced among the Essenes and in the Qumran community, I propose to compare this doctrine with that of the Pharisees and Sages of the first generations. As to the Pharisees, Josephus reports that for them: 'Certain events are the work of Fate, but not all; as to the other events, it depends upon ourselves whether they shall take place or not' (Antiquities XIII, 172).

This statement by Josephus on the Pharisees echoes the sentence of Rabbi Akiva: 'All is foreseen, but freedom of choice is given [to men]'

\footnotetext{
${ }^{13}$ War II, 162-165; Antiquities XIII, 171-173; XVIII, 11-22. On these three texts of Josephus, see F. Schmidt, 'Destin et providence chez Flavius Josèphe', in Pierre Vidal-Naquet, un historien dans la cité, eds F. Hartog, P. Schmitt and A. Schnapp (Paris, 1998) [hereafter Schmidt, 'Destin et providence'], pp. 18590.

${ }^{14}$ The word heimarmenê here is an equivalent of the divine Will; see Schmidt, 'Destin et providence', pp. 180-85.
} 
(Mishna, Avot III, 15) ${ }^{15}$ Is it possible to clarify, in the doctrine of the first Sages, the limits assigned to freedom of choice?

In attempting to answer this question I shall ask what happens to freedom of choice and human responsibility when faced with one of the most radical formulations of determinism, namely, the data inscribed in the stars. More precisely, in order to deal with the predictions concerning human lives, in which human beings usually appear to be completely stripped of any possibility of action, I shall investigate the question of lifespan and premature death in the horoscope: faced with what is seen as an ineluctable fatality, faced with the highest degree of determinism, what share of free initiative does the doctrine of the Sages concede to humans?

\section{Is Israel subject to astral influence?}

One of the most characteristic and most famous pages of the Talmud on the diversity of the opinions of the Amoraim concerning astrology, and more particularly the horoscope, can be read in TB Shabbat 156 a-b. From the discussion as it develops here, the section most commonly recalled concerns the words of Amora R. Johanan, 'there is no mazzal for Israel', as meaning that, unlike other nations, Israel is not subject to astral influence. ${ }^{16}$ Is R. Johanan's point of view actually that of an adversary of

${ }^{15}$ I prefer the classic interpretation of ha-kôl tsafûi as implying the idea of foreknowledge. However, according to E. E. Urbach, The Sages. Their Concepts and Beliefs (Cambridge, MA/London, 1987) [hereafter Urbach, Sages], pp. 256258 , this expression implies neither the idea of predestination nor that of prescience. For Urbach, the use of tsafa in the sense of 'know in advance' is not attested before the Amoraim.

${ }^{16}$ Palestinian Amora of the second generation, R. Johanan bar Nappaha (ca. 180279 ) is the founder of the Academy of Tiberias. Among the numerous commentaries of TB Shabbat $156 \mathrm{a}-\mathrm{b}$, see particularly L. Wächter, 'Astrologie und Schicksalsglaube im rabbinischen Judentum', Kairos. Zeitschrift für Religionswissenschaft und Theologie (1969) [hereafter Wächter, 'Astrologie und Schicksalsglaube'], Neue Folge XI, pp. 189-92; J. H. Charlesworth, 'Jewish Astrology in the Talmud, Pseudepigrapha, the Dead Sea Scrolls, and early Palestinian Synagogues', Harvard Theological Review (1977), vol. 70, pp. 18588; resumed in J.H. Charlesworth, 'Jewish Interest in Astrology during Hellenistic and Roman Period', in Aufstieg und Niedergang der römischen Welt II, 20.2 (Berlin/New York, 1987) [hereafter Charlesworth, 'Jewish Interest'], pp. 930-32; S. A. Goldberg, La Clepsydre II. Temps de Jérusalem, temps de Babylone (Paris, 2004), pp. 69-84; and particularly K. von Stuckrad, Das Ringen

Culture and Cosmos 
astrology, resolutely opposed to any astrological practice in Israel? Or is he merely stressing the conditional and non-absolute aspect of astral determinism?

The first part of the controversy addresses the method of establishing mazzal and the predictions that can be drawn from it. Are psychological or moral characteristics, fortune, professional activity or the manner of death, contingent on the mazzal of the day or the mazzal of the hour? The term mazzal, which appears in the plural in II Kings 23, 5 in the sense of 'zodiacal constellations' is employed here in the singular in the sense of 'astral theme'. ${ }^{17}$

R. Hanina, a first-generation Palestinian Amora, ${ }^{18}$ concludes this first part by stating: "the astral theme gives wisdom, the astral theme gives wealth, there is an astral theme for Israel'. To which R. Johanan retorts: 'there is no astral theme for Israel', and in support of his thesis, quotes the scriptural argument of Jeremiah 10, 2: 'Facing the signs in the heavens, fear not! It is the nations who fear them'.

\section{Three tales}

Three accounts, all three about the children of Israel, then illustrate R. Johanan's point of view. In the first, Ablat, a foreign astrologer, seeing a man walking towards a pond, ${ }^{19}$ predicts to Samuel that the man will die, bitten by a snake. 'If this man is a son of Israel', Samuel retorts, 'he will go and return'. ${ }^{20}$ In fact, thanks to a righteous act (tsedaqah), the man

um die Astrologie. Jüdische und christliche Beiträge zum antiken Zeitverständnis (Berlin - New York, 2000) [hereafter von Stuckrad, Das Ringen], pp. 461-80.

${ }^{17}$ I understand mazzal as a 'demythologized' equivalent of the Hebrew môlad which, in its Qumran uses, as mentioned above, means the 'theme of geniture'.

${ }^{18}$ Identified by Charlesworth, 'Jewish Interest', p. 931, as R. Hanina bar Hama, of Babylon, who directed the Academy of Sepphoris in the early third century, and who was the teacher of R. Johanan. On the contrary, von Stuckrad, Das Ringen, pp. 471-72, proposes to identify this R. Hanina as a Palestinian Amora of the second generation.

19 'gm' : a 'pond' or a 'meadow'.

${ }^{20}$ Samuel, or Mar Samuel called 'Yarhinaah' (versed in the calculation of the lunar year), first generation Babylonian Amora according to Wächter, 'Astrologie und Schicksalsglaube', p. 190 and note 36. On Ablat, ibid., p. 190 and note 37 .

Culture and Cosmos 
34 Horoscope, Predestination and Merit in Ancient Judaism

eludes the death announced by the astrologer.

The second story depicts R. Akiva and his daughter. The Chaldeans (kld'y) had predicted that she would die on her wedding day, also bitten by a snake. On the appointed day, the prediction of the astrologer is again disproved. Having performed a righteous act to a poor man, Akiva's daughter escapes a premature death. The account ends with the words of her father: "Righteousness (tsedaqah) saves from death" (Pr. 10, 2) - not from death itself, but from violent death'. ${ }^{21}$

The third story relates the opposite, a prediction that actually comes true. Astrologers (kld'y) have declared to the mother of R. Nahman that her son would be a thief. ${ }^{22}$ While in the two previous accounts, righteous acts by the man at the pond and the daughter of R. Akiva had countered the prediction of their respective astral theme, in the case of R. Nahmman, it was sufficient for him, against his mother's advice, to momentarily abandon study and prayer. Thus instantly delivered to his evil inclination (yetser), he commits a theft and the prediction about him comes true.

\section{What can we conclude from this Talmudic debate?}

How are we to interpret the statement by R. Johanan according to which 'there is no mazzal for Israel'? The finding that the astrological predictions materialise when they are not countered by righteous acts (as in the example of R. Naḥman), indicate that R. Johanan's intention is not to condemn outright any Jewish practice of astrology. As shown by Kocku von Stuckrad, the focus of R. Johanan's critique, as well as the three accounts which illustrate his thesis, is to reject any interpretation of the horoscope, and particularly of the astral theme (mazzal) as implying a fatum, in other words, an irrevocable fate to which human is ineluctably doomed. $^{23}$ In Alexandria in the second century, Claudius Ptolemy, questioning in his Tetrabiblos the utility of predictions, also warns

21 As noted by Urbach, Sages, pp. 264-65 and 804-05, note 35, this lesson attested in the compilation of the Haggadot ha-Talmud is more satisfactory, in this context, than the reading of the printed editions of TB Shabbat $156 b$ which is: 'not from violent death but from death itself'.

${ }^{22}$ Babylonian Amora of the fourth generation, R. Nahman bar Isaac (died ca. $356)$ is a contemporary of Rava.

${ }^{23}$ von Stuckrad, Das Ringen, pp. 478-80. 
against such a misinterpretation: 'Let us avoid believing that everything that happens to men is the effect of a cause coming from above, as if from the beginning, in accordance with some irrevocable and divine decree, everything had been settled in advance for each individual and

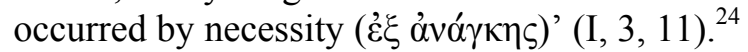

Because, he adds, while insisting on the relativism of astral determinism, 'If the event has been foreseen and the remedies applied,

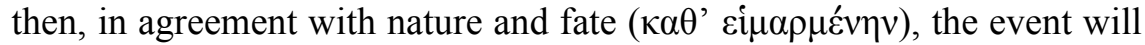
not occur or its effects will be attenuated' (I, 3, 13).

In R. Johanan's interpretation also, the misfortunes announced by the astrological predictions, like those diagnosed by doctors, can be forestalled, provided the appropriate remedies are applied: in this case, righteous acts. In the Jewish conception of astrology, attested by TB Shabbat 156a-b, astral determinations, far from being absolute, are relative; and evil predictions, far from being ineluctable, are conditional.

So what, finally, is the moral of the story of the man at the pond, and that of R. Akiva's daughter? These two accounts teach that for the children of Israel, even if the consultation of the astral theme foresees an early death, it is within their power to escape this prediction by opting for righteous behaviour. Thus, these two examples are an illustration in the field of genethlialogy - commonly considered as the place par excellence where the forces of an implacable fate converge, determining the course of individual lives - of this tension between divine prescience and free human choice that was formulated by R. Akiva in Mishna, Avot III, 15.

\section{Rabbi Akiva and the longevity of the righteous}

The words of R. Akiva, whereby acts of righteousness (tsedaqah) provide salvation, if not from death itself, at least from premature death, are clarified in TB Yevamot 49b-50a, ${ }^{25}$ on the occasion of an exegetic exchange between R. Akiva and other Sages on the interpretation of Ex. 23, 26: 'I shall fulfil the number of your days'. For R. Akiva, this verse refers to the 'years of the generations', in other words, the lifespan

\footnotetext{
${ }^{24}$ For this and other quotations from the Tetrabiblos, I am following the Greek text edited by F. E. Robbins, Ptolemy, Tetrabiblos (Cambridge, MA/London, 1994). The English translation is adapted from Pascal Charvet's French translation, Ptolémée, Le Livre unique de l'astrologie. Le Tétrabible de Ptolémée. Astrologie universelle et thèmes individuels (Paris, 2000), pp. 37 and 39.

${ }^{25}$ See Urbach, Sages, pp. 265 and 805, note 36.
} 
36 Horoscope, Predestination and Merit in Ancient Judaism

attributed to everyone at birth, ${ }^{26}$ and implies that the righteous complete their lifespan, but that conversely, the lifespan of sinners is shortened: 'These are the years of the generations. For one who is righteous, they are completed. For a sinner, the number is reduced'.

\section{Karet}

The idea that the lifespans of sinners are shortened presupposes the concept of karet which, in the Bible, designates the penalty of 'extirpation' for certain faults committed against God. ${ }^{27}$ The Mishna, in Keritot I, 1, compiles the biblical list of faults incurring the penalty of karet and names thirty-six transgressions. These are mainly faults of a ritual nature, like idolatry and illicit sexual relations. As to the nature of the punishment inflicted, the rabbis appear to agree that it is death occurring before the fixed time, but disagree on the question of the age at which a life is susceptible of being prematurely interrupted, and the age after which death can be thought to have occurred at the appointed time. For some, he who dies 'before fifty years dies struck by karet' (TJ Bikkurim II, 1); for others, 'between fifty and sixty years, it is death by karet' (TB Mo'ed Katan 28a). By contrast, once this particular age has been passed, this occurs at the ordained time, and can be held to be a natural death. Thus R. Joseph, on reaching the age of sixty, rejoices for having 'passed (the age of) karet' and escaped a premature death as punishment for a grave fault against God. The natural death of the righteous, filled with days, is thus opposed to the premature death of sinners.

This raises a predictable objection, the scandal of the premature death of the righteous compared with the longevity of sinners. ${ }^{28}$ Quoting the example of two sages who both led righteous lives, but of whom one

${ }^{26}$ On the biblical idea that a lifespan is attributed to everyone see Ex. 23, 26; Isa. 65,20 ; Ps. 39, 5; 90, 10. The righteous accomplish their whole lifetime: Gen. 25, 8; Deut. 4, 40; 5, 16; Job 42, 17. On the phrase 'the years of the generations' see Urbach, Sages, pp. 265-66 and 805, note 38 .

27 On the biblical concept of karet see J. Milgrom, Leviticus 1-16 (New York/London, 1991), pp. 457-60. On the division between crimes against persons which are punishable by a human court and crimes against God which are judged by God and punished by karet, see J. Milgrom, Leviticus 17-22 (New York/London, 2000), pp. 1420-21.

${ }^{28}$ Cf. Isa. 57, 1; Wis. 4, 16-17.

Culture and Cosmos 
lived only 40 years while the other lived to a ripe old age of 92, Rava objects: 'longevity, children and subsistence do not depend on merit (bzkwt') but on the astral theme (bmzl')' (TB Mo'ed Katan 28a). ${ }^{29}$ Contrary to R. Akiva for whom longevity depends both on the astral theme (mazzal) and righteous acts, for Rava, questions of longevity, offspring and means of subsistence depend exclusively on mazzal. For him, in these three areas, as attested by the example of the two sages, merit or righteous works are inoperative.

In fact, these three areas, which for Rava are exclusively determined by the astral theme, correspond to three topics of the treatises of Greek genethlialogy. Thus Claudius Ptolemy, in his Tetrabiblos, among the predictions that the science of the Mathematici aims to establish from an examination of the horoscope, enumerates material riches, ${ }^{30}$ children $^{31}$ and the manner of death. ${ }^{32}$ This correspondence indicates that these treatises of genethlialogy were not unknown to the Jewish astrologers scrutinizing the mazzal of those who came to consult them for answers to their questions.

\section{Abraham and the premature death of sinners}

The long recension of the Testament of Abraham, written in Greek, comes to us from Egyptian Judaism and probably dates from the early second century. ${ }^{33}$ 'Abraham reached the measure of his life at the age of

29 Babylonian Amora of the fourth generation, Rava (died ca. 352) is a contemporary of R. Nahman bar Isaac.

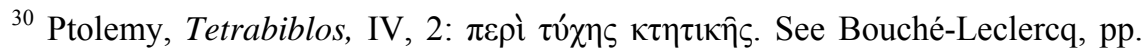
436-37.

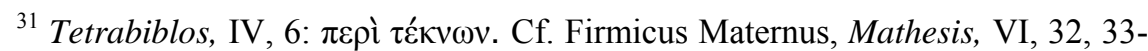
39; VII, 3, 1-7; 10, 1-5; 11, 1-6. See Bouché-Leclercq, pp. 451-53.

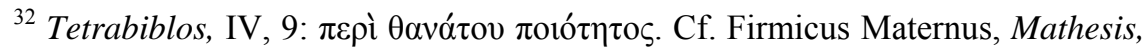
VII, 23, 1-29. See Bouché-Leclercq, pp. 422-28.

${ }^{33}$ For the Greek texts of Testament of Abraham see F. Schmidt, Le Testament grec d'Abraham. Introduction, édition critique des deux recensions grecques, traduction (Tübingen, 1986). For a commentary, see F. Schmidt, 'Testament d'Abraham', in Écrits Intertestamentaires, eds A. Dupont-Sommer et M. Philonenko (Paris, 1987), pp. 1647-1690, esp. pp. 1683-1688; D. C. Allison, Jr., Testament of Abraham (Berlin/New York, 2003) [hereafter Allison, Testament of Abraham], esp. pp. 333-80. On the date of the two Greek recensions see Allison, ibid., pp. 34-40. 
999 years'. The patriarch directly appears as the perfect model of the righteous man who reaches the end of the term of life assigned to him ( $\tau$ ò

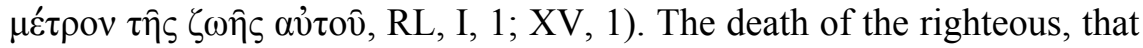
occurs 'at the fixed time' (o ' $\chi \chi \omega v$ ö $\rho o v, X X, 2$ ), contrasts with the

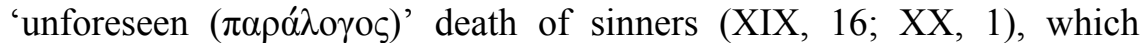

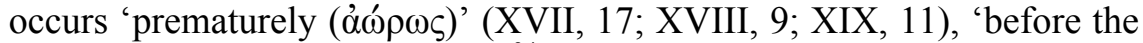

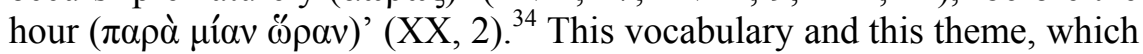
are absent from the short recension, are specific to the long recension. By contrasting the death of the righteous which occurs at the fixed term with the premature death of sinners, the long recension of the Testament stands as an account illustrating the statement of R. Akiva: For one who is righteous, the years will be complete. For a sinner, the number will be reduced' (TB Yevamot 50a).

The doctrine of the Testament of Abraham is thus found to agree with that of R. Akiva, which the Sages of later generations develop further. However, the Testament provides an additional detail on the various manners of death which prematurely remove sinners. In fact, before Abraham the righteous dies filled with days, Thanatos, the angel of Death, 'sheds his beauty' and appears in the form that he assumes when he goes before sinners: a form with seven dragons' heads and fourteen faces. At the request of the Patriarch, Thanatos transforms himself, shows his 'faces' (prosôpa), and gives their explanation: 'I have shown you,' he says, 'the face of a precipice, for many are those who die by falling from the top of a tree or from a precipice, and they see Death in the form of a precipice' (RL, XIX, 9), and so on for each of the seven faces.

Although the textual tradition of this passage is rather confused by the additions of copyists, it seems reasonable to reconstitute the following list of the seven faces of Thanatos: fire, the precipice, the sword, the river, the sea, savage beasts, and the cup of poison. Each of these faces corresponds to a type of accident that can prematurely end the sinner's life. Thus, we are dealing with premature death (aôros: RL XVII, 17; XVIII, 9; XIX, 11), or violent deaths, not by illness but by accident, deaths that Greek astrologers call biaiothanatoi. Genethlialogy predicts from birth whether one's death will be natural (kata phusin) or accidental (para phusin), and in the latter case, what type of accident will cut one's life short. The enumeration of various categories of biaiothanatoi constitutes an obligatory chapter in astrological treatises. From

\footnotetext{
${ }^{34}$ For Greek vocabulary on death that occurs 'at the fixed time' and untimely death see Allison, Testament of Abraham, pp. 356, 389-90.
} 
Critodemus, one of the successors of Berosus, in the mid-third century $\mathrm{BC}$, to Claudius Ptolemy or Vettius Valens, in the mid-second century $\mathrm{CE}$, everyone discusses types of death. In an individual's horoscope, depending on whether Saturn or Mars, the malevolent planets, are placed in one or another sign of the zodiac, what accident will put a premature end to one's life? Let us follow Ptolemy in Book IV of his Tetrabiblos. ${ }^{35}$

The first malevolent planet, cold and dry, is Saturn. ${ }^{36}$ In the signs with an animal form, Saturn causes death by wild beasts. If these signs are in the form of serpents, Saturn causes death by the bites of venomous animals; if Venus is present, by poisoning. In Virgo or Pisces, or other watery signs, when the Moon aspects (lit. 'is configured'), Saturn causes death by drowning; in the neighbourhood of Argo, by shipwreck. In the four-footed signs, if Saturn is with the Sun in the Midheaven or IC (culminating or anti-culminating), it causes death by falling from a height (IV, 9.10-11).

The second malevolent planet is Mars, its red colour being associated with blood. ${ }^{37}$ If Mars is with the Sun or the Moon in human signs, it causes death by war or murder; setting ${ }^{38}$ or opposed to the Ascendant, it causes death by fire (IV, 9.12).

Thus the seven faces of Thanatos - fire, precipice, sword, river, sea, savage beasts, and the cup of poison - correspond to the principal cases of violent death predicted by astrologers according to the position occupied by the malevolent planets in the horoscope. This correspondence tends to imply that in the milieu where the Testament of Abraham was written, there was a Jewish re-elaboration, adapted to the specific ethics of the Hellenized Judaism of Egypt, of the genethlialogical

\footnotetext{
${ }^{35}$ Ptolemy, Tetrabiblos IV, 9; see Bouché-Leclercq, pp. 422-25. As early as the third century BC, Critodemus listed the various categories of death. See F. Cumont, CCAG 8/4, pp. 199-202 [Excerpta ex Codice 82 (Paris. 2425)]: by poisoning (p. 199.19; p. 200.16); by wild beasts (p. 200.1, 11); by drowning (p. 200.5); by falling from a height (p. 200.9); by murder or war (p. 200.11); by fire (p. 201.14). On Critodemus see Wilhelm Gundel and Hans Georg Gundel, Astrologumena. Die astrologische Literatur in der Antike und ihre Geschichte (Wiesbaden, 1966), pp. 106-07.

${ }^{36}$ On Saturn see Bouché-Leclercq, pp. 93-97.

${ }^{37}$ On Mars see Bouché-Leclercq, pp. 98-99.

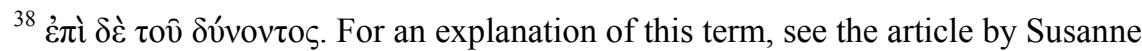
Denningmann in this volume.
}

Culture and Cosmos 
40 Horoscope, Predestination and Merit in Ancient Judaism

speculations on the manners of death as predicted by the Greek astrologers.

In fact, in the Testament of Abraham, these enquiries are only concerned with the death of sinners. In the Testament, premature and violent death spares the righteous, of whom Abraham is the model. As opposed to sinners, the righteous are not subject to the laws of genethlialogy. This difference in status in the face of death allows us to understand what conception of genethlialogy is implicitly at work in the Testament of Abraham. For the Greek astrologers, the type of death of an individual is determined by the astral configuration presiding over their birth or their conception. In the Jewish transposition of genethlialogy that the Testament of Abraham echoes, all human beings are not equally subject to astral determinism. Just as R. Akiva, making the exegesis of Proverbs 10, 2 and inquiring into the type of death predicted by the mazzal which is precluded by righteousness, concludes that righteousness spares one, if not from natural death, at least from accidental death, so in the Testament only those who choose the path of sin are subject to astral determinism; those who choose the path of righteousness are spared. For contrary to the opinion expressed later by Rava, for the Testament of Abraham and for R. Akiva, the lifespan and the manner of death are not dependent on mazzal alone, but depend both on mazzal and merit. The conception of the horoscope attested by the Testament of Abraham, far from confining humans in an implacable determinism, provides leeway for freedom of choice.

\section{Conclusion}

Originating from the Jewish Diaspora of Egypt and dating from the early second century, the long recension of the Testament of Abraham is contemporary with R. Akiva. The original milieu of this account and R. Akiva share the same conceptions of the death of the righteous filled with days and the premature death of sinners. For one and the other alike, only sinners find their lives interrupted and suffer the way of death predicted by their horoscope, while the righteous are freed from astral determinism. R. Akiva's example also implies that questions of astrology were already debated in the era of the Tannaim. The foreign model, which had been demythologized and then remythologized ${ }^{39}$ to make it conform to Jewish categories, is the Greek model at least as much as the Babylonian one.

${ }^{39}$ I take this formulation from Charlesworth, 'Jewish Interest', p. 929. 
As for the Sages, the foregoing analyses, far from highlighting a common position, make different voices heard. For Rava, man, if not in all circumstances, at least on certain questions, beginning with those of lifespan and the manner of death, appears helpless, completely dependent on his astral theme (TB Mo'ed Katan 28a); R. Hanina is also of the opinion that there is a mazzal for Israel, conditioning wisdom and wealth. As for R. Johanan (under the influence of Maimonides' interpretation, often seen as the spokesman of the idea that astrology stops at the boundaries of Israel), he condemns astral fatalism; in doing so, he implicitly recalls that the predictions drawn from the stars are conditional, and stresses responsibility and freedom of choice (TB Shabbat $156 \mathrm{a}-\mathrm{b}$ ). Ultimately, R. Johanan's point of view matches the teachings of R. Akiva. In this conception, which affirms both mazzal and merit, it depends on the observance of the precepts whether or not astral determinism, even the most inexorable, can be neutralized (TB Yevamot 49b-50a).

No doubt these many voices, each proposing a different solution to the tension enunciated by R. Akiva between divine prescience and human freedom (Mishna, Avot III, 15), have in common with all the Jewish conceptions of astrology, including the conception developed by the Qumran community, the idea of seeing the stars, not as Powers, but as objects created, subject to God the creator and accomplishing His Will. Yet the Qumranian and rabbinical conceptions diverge on essential points. On the line stretching between the two opposite poles, that of absolute determinism and that of complete freedom of choice, the Qumranian position lies very close to determinism. On the contrary, the more nuanced positions of the Sages approach the other pole, that of free choice. Qumranian astrology, and genethlialogy in particular, constitute a revealed knowledge, and form part of the Mysteries transmitted by revelation to the Mevinîm, to 'those who can discern'. Conversely, discussions of the pros and cons of astrology rather show that, for the Sages and within the Hellenized Judaism of Egypt, astrology represents a human knowledge subject to reasoning and controversy. In Qumranian spirituality, those who are discerning scrutinize the 'Mystery that is to be' and question the theme of geniture (môlad) as a way to bend their action to the divine Will. ${ }^{40}$ In the teaching of the Sages, the questioning of the astral theme (mazzal), far from revealing any divine verdict to which human being is ineluctably bound, offers him the freedom of neutralizing the direst predictions by repentance and righteous acts.

\footnotetext{
${ }^{40}$ Schmidt, 'Recherche', pp. 58-59.
} 